\title{
The Effects of Basil on Blood Glucose Changes and Testosterone Levels in Streptozotocin Include Diabetic Rats
}

\author{
Arash Khaki (PhD) \\ Department of Pathobiology, Tabriz \\ Branch, Islamic Azad University, Tabriz, \\ Iran \\ Corresponding Author: Arash Khaki \\ Email: khaki@iaut.ac.ir \\ Tel:+989143138399
}

Address: Department of Pathobiology, Tabriz Branch, Islamic Azad University, Tabriz, Iran

Received: 06 May 2014

Revised: 22 May 2014

Accepted: 02 Jun 2014

\section{ABSTRACT}

Background and Objective: According to Iranian, Asian, Indian, and Chinese traditional medicine, basil is used in the treatment of different diseases. In this study, the effect of basil on lowering the blood glucose was examined in healthy and diabetic rats.

Methods: Sixty Wistar rats were divided into a control group $(\mathrm{n}=10)$, a basil receiving group $(\mathrm{n}=20)$ and a diabetic group $(\mathrm{n}=30)(60 \mathrm{mg} / \mathrm{kg}$ Streptozotocin- Intraperitoneal injection $)$ and the rats in each group received basil orally in pairs. Forty-eight hours after injection of streptozotocin, 2 and $4 \mathrm{mg} / \mathrm{kg}$ doses of basil were prescribed orally for the diabetic group daily for 45 days. in end of study for record serum testosterone ,5 cc blood was sampled from each rat.

Results: There was a significant correlation between the oral administration of 2 and 4 $\mathrm{mg} / \mathrm{kg}$ doses of basil and reduced blood glucose level and testosterone changes in the diabetic groups $(\mathrm{P}<0.05)$. Twenty-four hours after the first administration, basil caused a significant decrease in the blood glucose level and this effects continued for 24, 40, and 72 hours, respectively. In contrast, basil had no hypoglycemic effect in the healthy rats.

Conclusion: The results indicated that 2 and $4 \mathrm{mg} / \mathrm{kg}$ doses of basil had significant hypoglycemic effects on the diabetic groups and compensated for the testosterone level in diabetic rats, but had no effect on the healthy rats.

Keywords: Streptozotocin, Testosterone, 0cimum Basiilicum, Diabetes Mellitus. 


\section{INTRODUCTION}

According to the Iranian traditional medicine, some herbs can be effective in the treatment of infertility, including fenugreek, ginger, nettle, raspberries, bananas, cauliflower, onions, red and green pepper, licorice, and pumpkin seeds. There is a growing interest in identifying antioxidants to understand the mechanism of the effect of damagingfactors on vital tissues through oxidation and release of free radicals and the bioactive compounds in herbal extracts are of particular importance, because they are obtained from the natural resources and are compatible with vital systems. Hyperglycemia affects the function of different organs, such as liver in the long term. Liver dysfunction is commonly seen in diabetic patients, especially those who have poorly controlled blood glucose (1). Diabetes mellitus includes a syndrome that disrupts metabolism of fats, carbohydrates, and proteins through increased blood glucose and increases the risk of vascular diseases $(2,3)$. Increased oxidative stress and changes in the level of antioxidants significantly contribute to the pathogenesis ofdiabetes mellitus (4-6). Although the exact mechanism of diabetesmellitushas not been well known, increased production of free radicals is among its main damaging mechanisms (7-9). Diabetesis consideredas an important endocrine diseasein which theregulation of carbohydrate metabolismis disrupted (10). These changes will increase the production of free radicals (11-13). The presence of antioxidants, such as vitamins and flavonoids in the dietcan have protective effect sindiabetic patients (14-16). Given the importanceofbasilas an aromatic and therapeutic herb in the dietandIranian traditionalmedicine, this study aimed to examine the effect of oral administration of basil on lowering the blood glucose in healthy and diabetic rats.

\section{MATERIAL ANDMETHODS:}

Fresh basil was bought in the summer and was dried using shadow-open-air method. The dried leaves were milled and kept in a refrigerator. Each rat used 3 gr of the powder daily for 45 days.
Phamacia \& Upiohn:USA) was dissolved in 0.5 $\mathrm{ml}$ of distilled water and was injected intraperitoneally. Then, the blood glucose level was measured every 24 hours. After 24 hours, a significant decrease in blood glucose level was observed and these effects remained for 7 days (10).

Blood samples were taken to measure the level of blood glucose from the tail vein of the rats before injectingstreptozotocin and 48 hours after injectingstreptozotocin. To measure the blood glucose level, one touch glucometer(Lifescan; Johson\& Company; Germany) was used. The rats whose blood glucose was $300 \mathrm{mg} / \mathrm{dl}$ were selected for experiment. Male Wistar rats weighing $250 \pm 10$ gr were randomly divided into healthy and diabetic groups. The study was conductedusing two protocols. Inthe first protocol, the healthy rats orally received dried basil powder. The healthy rats receiving this herb were divided into 3 subgroups of 10 rats. They received normal saline $(1 \mathrm{ml})$, dried basil orally, and dried basil mixed with the food at a rate of 2 and $4 \mathrm{mg} / \mathrm{kg}$, respectively. The rats' blood glucose levels were measuredimmediatelyand also $1,2,4,6$, and 8 hours after intraperitoneal injection of streptozotocin $(60 \mathrm{mg} / \mathrm{kg})$. One of the subgroups, as the diabetic control group, received normal saline and the other two subgroups, as the treatment groups,orally received 2 and $4 \mathrm{mg} / \mathrm{kg}$ of basil powder, respectively, 72 hours after injection of streptozotocin and every 10 hours after the first administration ofthe extract. The blood glucose levels of these rats were measured before injectingstreptozotocin, as well as 50, 68, 88, and 119 hours after the injection.

blood testosterone level were measured using radioimmunoassay kits (Biosource, Belgium).

ANOVA was used to analyze and compare the results in the groups.

\section{RESULTS}

Twenty-four hours after the intraperitoneal injection of a single dose of $60 \mathrm{mg} / \mathrm{kg}$ streptozotocinto rats, a significant increase in the glucose levels was observed in all groups $(\mathrm{P}<0.001)$, so that the blood glucose level in the control group was about 25 times its initial value. This increase in blood glucose level continued for 7 days. 
The consumption of dried powder of basil orally at both doses significantly reduced the STZinduced blood glucose 24 hours after the first administration of extract $(\mathrm{P}<0.05)$ and these effects remained for 72,48 , and 24 hours, respectively.Time had no significant effect on the blood glucose level in diabetic rats. The
Streptozotocin-induced diabetes: To induce diabetes, $60 \mathrm{mg} / \mathrm{kg}$ of streptozotocin (Zanosar; results of hormone analysis indicated a significant reduction in the testosterone level of diabetic groups compared with that ofthe control group $(\mathrm{P}<0.05)$. Also, the reduction in the level of this hormone was significantly compensated for the diabetic groups receiving basil $(\mathrm{P}<0.05)$

Table1- Changes in blood glucose and testosterone levels in different groups

\begin{tabular}{lcc}
\hline \multicolumn{1}{c}{ Groups } & $\begin{array}{c}\text { Blood glucose } \\
(\mathrm{Mg} / \mathrm{dl})\end{array}$ & $\begin{array}{c}\text { Testosterone } \\
(\mathrm{ng} / \mathrm{ml})\end{array}$ \\
\hline Control group & $\mathbf{1 0 6 . 7 \pm 0 . 0 5}$ & $1.65 \pm 0.05$ \\
2mg/kg basil & $108.6 \pm 0.05$ & $3.05 \pm 0.05^{*}$ \\
$4 \mathrm{mg} / \mathrm{kg}$ basil & $111.5 \pm 0.05$ & $2.99 \pm 0.05^{*}$ \\
Diabetic group & $376.5 \pm 0.05^{* *}$ & $0.85 \pm 0.05^{*}$ \\
Diabetic group receiving 2mg/kg & $280.6 \pm 0.05^{*}$ & $1.05 \pm 0.05^{*}$ \\
Diabetic group receiving 4mg/kg & $265.5 \pm 0.05^{*}$ & $1.15 \pm 0.05^{*}$ \\
\hline
\end{tabular}

$*: P$ value $<0.05$

$* *$ :P value $<0.001$

\section{DISCUSSION}

There are many compounds, whose antidiabetic effects have been proven, including quercetin, peptides, amines, lipids, and flavonoids (12, 13). Disrupted glucose metabolism and incidence of hyperglycemia cause the genes associated with storage of fatty acids become activated in the liver cells (4).Flavonoidsare antioxidants found infruits, vegetables, tea, and black grapes (17-20). This study clearly indicated that some antioxidants existing in the herbs have a significant hypoglycemic effect in diabetic rats, while they have no effect on lowering the blood glucose in healthy animals. In other words, the ethanol extract of these herbs, like Biguanidin medications act like metforminand these medications act like a euglycemic factor. After administration of basilatdoses of 2 and $4 \mathrm{mg} / \mathrm{kg}$, the measurement of blood glucose in healthy animals indicated that basil had no effect on lowering blood glucose level in healthy animals, but when it was used 48 hours after the STZ injection, the blood glucose levels of animals significantly reduced $(\mathrm{P}<0.05)$. The results also indicated that the hypoglycemic effect of basil in diabetic animals at doses of 2 and $4 \mathrm{mg} / \mathrm{kg}$ significantly compensated for the testosterone level in the blood $(\mathrm{P}<0.05)$. Dose-independent effects and different effects at different doses can be attributed to blood glucose increasing constituents in the plant. Mechanisms suggested for antioxidant compounds existing in some plants, including tannins and terpinoids, quercetin, myricetin, peptides, and flavonoids include stimulation of glycogenesis, blocking potassium channels in pancreatic beta cells, and regulation of intestinal glucose absorption (12). Due to the flavonoid compounds existing in basil, its anti-diabeticeffectindiabeticratsseems to be due to these flavonoids (4).

\section{CONCLUSION}

It concluded reducing blood sugar has beneficial effects on serum testosterone regulation level.

\section{ACKNOWLEDGMENTS}

I would like to thank the Department of Pathology, Faculty of Veterinary Medicine, Tabriz Branch, Islamic Azad University for their assistance in this study.

\section{CONFLICT OF INTEREST}

There are no conflicts of interest. 



\section{REFERENCES}

1. Sarahroodi S, Esmaeili S, Mikaili P, Hemmati Z, Saberi Y. The effects of green Ocimum basilicum hydroalcoholic extract on retention and retrieval of memory in mice. Ancient Sci Life. 2012; 31(4): 185-9. doi: 10.4103/02577941.107354.

2. Holstein A, Hinze S, Thiessen E, Plaschke A, Egberts EH. Clinical implications of hepatogenous diabetes in liver irrhosis. J Gastroenterol Hepatol. 2002; 17(6): 677-68.

3. Blank AF, Rosa YR, Carvalho Filho JL, Santos CA, Arrigoni-Blank MF, Niculau ES, et al. A diallel study of yield components and essential oil constituents in basil (Ocimum basilicum L.). Ind Crops Prod. 2012; 38: 93-8. doi:10.1016/j.indcrop.2012.01.015.

4. Sakr SA, Nooh HZ. Effect of Ocimum basilicum extract on cadmium-induced testicular histomorphometric and immunohistochemical alterations in albino rats. Anat Cell Biol. 2013; 46(2): 122-130. doi: 10.5115/acb.2013.46.2.122.

5. Gruenwald J, Brendler T. PDR for herbal medicines. $3^{\text {rd }}$ ed. Thomson PDR at Montvale. 2004; 861-862.

6. Harnafi H, Aziz M, Amrani S. Sweet basil (Ocimum basilicum L.) improves lipid metabolism in hypercholesterolemic rats. E Spen Eur E J Clin Nutr Metab. 2009; 4(4): 181-186. doi:10.1016/j.eclnm.2009.05.011.

7. Khaki A, Fathiazad F, Nouri M, Khaki AA. Effect of Ocimum basilicum on apoptosis in testis of rats after exposure to electromagnetic field. Afr J Pharm Pharmacol. 2011; 5(12): 1534-1537.

8. Markham KR. Technique of flavonoid identification. Academic Press, London. 1982.

9. Dasgupta T, Rao AR, Yadava PK. Chemomodulatory efficacy of basil leaf (Ocimum basilicum) on drug metabolizing and antioxidant enzymes, and on carcinogeninduced skin and forestomach papillomagenesis. Phytomedicine. 2004; 11(2-3): 139-151.

10. Rush E, Crook N, Simmons D. Point-of-care testing as a tool for screening for diabetes and pre-diabetes. Diabet Med. 2008; 25(9): 1070-5. doi: 10.1111/j.14645491.2008.02526.x.

11. Marles RJ. World Health Organization -diabetes mellitus, Report of WHO study group. Journal of Botanical Medicine. 1996; 1(3): 85-135.
12. Hosseinzadeh H, Ramezani M, Danaei AR Antihyperglycemic Effect \& Acute Toxicity of Securigera securidaca $L$ Seed Extracts in Mice. Phytotherapy Research. 2002; 16(8): 745-747.

13. Dokania M, Kishore K, Sharma P. Effect of Ocimum sanctum extract on sodium nitrite-induced experimental amnesia in mice. Thai J Pharm Sci. 2011; 35(3): 123-30.

14. Custro N, Carroccio A, Ganci A, Scafidi V, Campagna P, Di Prima L, Montalto G. Glycemic homeostasis in chronic viral hepatitis and liver cirrhosis. Diabetes Metab. 2001; 27(4pt1): 476-481.

15. Harnafi H, Aziz M, Amrani S. Sweet basil (Ocimum basilicum L.) improves lipid metabolism in hypercholesterolemic rats. E Spen Eur E J Clin Nutr $\begin{array}{lll}\text { Metab. } & \text { 2009; } & \text { 4(4): }\end{array}$ doi:10.1016/j.eclnm.2009.05.011.

16. Khaki A, Nouri M, Fathiazad F, Ahmadi-Ashtiani HR, Rastgar H, Rezazadeh Sh. Protective Effects of Quercetin on Spermatogenesis in Streptozotocin-induced Diabetic Rat. iranian journal of medical plants. 2009; 8(5): 57-64.

17. Khaki A, Khaki AA, Hajhosseini L, Sadeghpour Golzar F, Ainehchi N. The Anti-Oxidant Effects of Ginger and Cinnamon on Spermatogenesis Dys-function of Diabetes Rats. Afr J Tradit Complement Altern Med. 2014; 11(4): 18.

18. Khaki A, Fathiazad F, Nouri M, Khaki A, Maleki NA, Khamnei HJ, Ahmadi P. Beneficial effects of quercetin on sperm parameters in streptozotocin-induced diabetic male rats. Phytother Res. 2010; 24(9): 1285-91. doi: 10.1002/ptr.3100.

19. Laleh Hajhosieni, Fatemeh Fallah Rostami, Arash Khaki. Bioflavonoids Effects of Ginger on Glomerular Podocyte Apoptosis in Streptozotocin-induced Diabetic Rat. CJMB. 2014; 1(2): 42-45.

20. Khaki AA, Khaki A, Nouri M, Ahmadi-Ashtiani HR, Rastegar H, Rezazadeh Sh, et al. Evaluation Effects of Quercetin on Liver Apoptosis in Streptozotocin-induced Diabetic Rat. iranian journal of medical plants. 2009; 8(5): 70-78. 